\title{
Effect of Delayed Elevation of Thyrotropin on Feeding Intolerance in Very Low Birth Weight Infants
}

\author{
Ju Kyung Hyun ${ }^{1}$, So Yoon Choi ${ }^{2}$, Yu Jin Jung ${ }^{1}$, and Jung Hyun Lee ${ }^{1}$ \\ ${ }^{1}$ Department of Pediatrics, Kosin University Gospel Hospital, Kosin University College of Medicine, Busan, Korea \\ ${ }^{2}$ Department of Pediatrics, Inje University Haeundae Paik Hospital, Inje University College of Medicine, Busan, Korea
}

\section{ABSTRACT}

Purpose: We investigated the effect of delayed elevation of thyrotropin (TSH) (deTSH) on gastrointestinal motility in very low birth weight infants (VLBWI).

Methods: This study retrospectively investigated 228 premature VLBWI aged $\geq 4$ weeks with normal neonatal TSH screening test results and free serum thyroxine levels. Infants with serum TSH levels ranging from 5 to $10 \mu \mathrm{IU} / \mathrm{mL}$ were categorized as the deTSH group ( $n=76)$, when TSH was measured at $4(n=53), 8(n=20)$, or $12(n=3)$ weeks of age. Serum TSH levels in the control group ( $n=152)$ were $<5 \mu \mathrm{IU} / \mathrm{mL}$. Multivariate logistic regression analysis was used to determine the risk factors for the development of deTSH. Covariance analysis was used to analyze the relationship between deTSH and gastrointestinal motility.

Results: The mean gestational age and birth weight were $29.11 \pm 2.25$ weeks and $1,157.4 \pm 218.0 \mathrm{~g}$, respectively. Risk factors affecting deTSH were dopamine administration (odds ratio [OR], 8.71; 95\% confidence interval [CI], 1.80 to $42.05 ; P=0.007$ ) and operation time (OR, $6.95 ; 95 \% \mathrm{CI}, 1.43$ to $33.75 ; P=0.016$ ) when the cumulative operating time was $\geq 1$ hour. The mean \pm standard deviation (SD) duration of a nil per os (NPO) status was significantly higher in the deTSH (99.57 \pm 134.99 hours) than in the control group (37.25 \pm 59.02 hours) ( $P$ from analysis of covariance [ANCOVA] $=0.001$ ). The mean \pm SD duration $(33.84 \pm 22.34$ days) of total parenteral nutrition (TPN) was considerably longer in the deTSH group than in the control group (27.68 \pm 13.08 days) ( $P$ from ANCOVA $=0.003$ ).

Conclusion: Clinicians must consider deTSH in VLBWI showing feeding intolerance with a prolonged NPO and TPN status.

Key Words: Infant, very low birth weight; Thyrotropin; Dopamine; Parenteral nutrition

\section{서론}

신생아에서 갑상샘기능이상(euthyroid sick syndrome, ESS)은 내분비 질환 중 가장 흔하며, 신 생아 3,000 명에서 4,000 명당 1 명의 비율로 발생한다 ${ }^{1)}$. 갑상샘호르몬은 산소 소비의 증가, 단백 합
Received: 17 September 2018

Revised: 25 January 2019

Accepted: 3 February 2019

Correspondence to: Jung Hyun Lee

Department of Pediatrics, Kosin University Gospel Hospital, Kosin University College of Medicine, 262 Gamcheon-ro, Seo-gu, Busan 49267, Korea Tel: +82-51-990-6121

Fax: +82-51-990-3005

E-mail: agasoa@kosin.ac.kr https://orcid.org/0000-0002-0496-9826

Copyright(c)

By Korean Society of Neonatology.

All right reserved.

This is an Open-Access article distributed under the terms of the Creative Commons Attribution Non-Commercial License (http://creativecommons.org/licenses/ by-nc/4.0), which permits unrestricted non-commercial use, distribution, and reproduction in any medium, provided the original work is properly cited. 
성 촉진과 중추 신경계 등의 각 기관의 성장과 발달, 조혈 기능 증가 등의 여러 과정에 관여하며, 신생아에서 성장과 지능 발달에 있어 중 요한 호르몬으로, ESS에 대해 적절한 시기에 진단과 치료를 하지 않 을 경우 지능 저하와 성장 장애 및 발달 지연을 나타낼 수 있다 ${ }^{2,3)}$. ESS 의 조기 발견을 위해 우리나라는 1997년부터 모든 출생아를 대상으 로 신생아선별검사(neonatal screening test, NST)를 시행하고 있다.

극소저체중출생아(very low birth weight infants, VLBWI)는 NST에 서 정상이었으나 신생아집중치료실에서 치료받는 동안 갑상샘자극 호르몬(thyroid stimulating hormone, TSH)의 지연된 상승을 보이고 치료가 필요한 경우가 있어 갑상샘 기능의 주기적 검사가 필수적이 다 $^{4-7)}$.

$\mathrm{TSH}$ 는 건강한 신생아에서 출생 30-60분에 급상승하였다가 생 후 5-7일 동안 감소한다 ${ }^{4)}$. TSH의 급상승으로 인해 유리 티록신(free thyroxine 4, FT4), 트리요오드타이로닌(triiodothyronine, T3) 분비가 촉진되어 24-36시간에 절정을 이루게 되고 생후 3-4일에 정상으로 감소한다 ${ }^{8,9)}$.

미숙아의 경우 뇌하수체-시상하부-갑상샘 축의 미숙과 갑상샘호 르몬의 불완전한 대사로 인해 갑상샘 기능 저하 상태에서도 TSH의 상승이 지연되며 ${ }^{10)}$, 정상 신생아보다 갑상샘 기능에 영향을 줄 수 있 는 질병에 더 쉽게 이환된다 ${ }^{11)}$. VLBWI에서 도파민이나 스테로이드, 푸로세미드와 같은 약물이나 수혈에 대한 노출이 많아 ESS를 보이는 경우가 많고 ${ }^{12)}$, 채혈이나 도관 삽입 등의 소독 과정 중에 요오드가 포 함된 소독제에 노출된 경우 $\mathrm{TSH}$ 의 일시적 혹은 지속적인 상승이 보 고 되었다 ${ }^{13)}$. VLBWI에서 ESS가 있는 경우, 첫 태변 배출의 지연, 장관 수유 진행이 원활하지 않은 등의 위장관 운동의 저하를 자주 경험하 게 된다 ${ }^{14)}$.

저자들은 갑상샘호르몬 치료를 받지 않은 VLBWI에서 신생아집중 치료실에 입원하며 치료하는 동안 지연성 TSH 상승에 영향을 미칠 수 있는 위험 요인들과 지연성 TSH 상승이 위장관 운동에 미치는 영 향에 대해 알아보고자 본 연구를 시행하였다.

\section{대상 및 방법}

\section{1. 대상}

2007년 3월 1일부터 2013년 3월 31일까지 고신대학교 복음병원 신생아집중치료실에 입 원한 37주 미만의 미숙아 가운데 출생 시 처 중이 $1,500 \mathrm{~g}$ 미만인 VLBWI는 382명이었다. 갑상샘 질환으로 과 거에 치료를 받았거나 현재 치료 중인 산모에게서 출생한 신생아 와 입원 기간 중 사망 또는 선천성 기형을 동반한 신생아 그리고 선 천 갑상샘저하증(영구적, 일시적, 타원으로 전원), 저티록신혈증 (hypothyroxinemia)을 제외한 총 228명이 연구의 대상에 포함되었다 (Figure 1). 본 연구는 의무기록을 후향적으로 분석한 것으로, 연구자
의 동의서 취득이 면제되었으며 고신대학교 복음병원 임상시험심사 위원회의 승인(IRB No. 2013-08-079)을 받았다.

\section{2. 방법}

ESS의 조기 발견을 위한 NST는 환자의 발꿈치에서 채취한 혈액을 여과지에 묻혀서 TSH 단독 검사로 출생 7-10일에 시행하였고, 그 결 과 값이 $10 \mu \mathrm{U} / \mathrm{mL}$ 이상을 비정상인 경우로 보고 반복 검사하였고, $\mathrm{TSH}$ 가 $20 \mu \mathrm{U} / \mathrm{mL}$ 이상인 경우 혈청 $\mathrm{TSH}$ 결과에 상관없이 갑상샘호 르몬 보충을 시작하였으며 ${ }^{6,7)}$, 혈청 TSH와 FT4가 태아 시기에 대부분 모체에 의존하다가 출생 후 그 영향이 줄어드는 시점인 출생 4 주째 화학발광면역측정법(chemiluminescence immunoassay)을 사용하여 측정하였다. 본원 신생아집중치료실 기준에 따라 갑상샘 기능은 혈 청 $\mathrm{TSH}$ 가 $5 \mu \mathrm{IU} / \mathrm{mL}$ 이하인 경우 정상으로 하였고, FT4의 정상범위 는 2010년까지는 0.89-1.8 ng/dL, 2011년 이후로는 0.78-1.54 ng/dL 로 하였다. VLBWI에서 출생 4주째 FT4가 정상 범위 미만이면서 혈 청 $\mathrm{TSH}$ 가 $10 \mu \mathrm{IU} / \mathrm{mL}$ 이하인 경우 저티록신혈증(hypothyroxinemia) 로 정의하였다. FT4가 정상이면서 혈청 $\mathrm{TSH}$ 가 5-10 $\mu \mathrm{IU} / \mathrm{mL}$ 인 경우 지연성 TSH 상승(delayed elevation of TSH, deTSH)으로 정의하였다 (Figure 1). 저티록신혈증과 지연성 TSH 상승의 경우 2주마다 추적검 사를 시행하였고, 결과가 정상인 경우에도 입원 기간이 장기간인 환 자에 한해 4 주마다 추적검사를 시행하였다. VLBWI에서 출생 4 주째 갑상샘 기능이 정상인 환자가 8주째, 12 주째 추적검사에서 혈청 $\mathrm{TSH}$ 가 5-10 $\mu \mathrm{IU} / \mathrm{mL}$ 로 상승한 경우도 deTSH로 간주하였다(Figure 1). 출 생 4주째 FT4가 정상 또는 저하이면서 혈청 TSH가 $10 \mu \mathrm{IU} / \mathrm{mL}$ 이상인 경우 선천 갑상샘저하증으로 정의하고 갑상샘호르몬 보충을 시작하 였고, 투약 후 3 년째 1달 정도 끊은 후에 갑상샘 기능이 정상이면 일 시적 갑상샘저하증으로 진단하였고, 비정상이면 영구적 갑상샘저하 증으로 진단하였당.

본 연구에서는 환자들의 성별, 재태 연령, 출생체중, 분만 방법, 1 분, 5 분 아프가 점수, 부당경량아(small for gestational age)를 조사 하였고, 신생아집중치료실에 입원 중 미숙아에서 이환율이 높은 신 생아 호흡곤란증후군(respiratory distress syndrome), 기관지폐형 성이상(bronchopulmonary dysplasia), 동맥관개존(patent ductus arteriosus, PDA), 신생아 괴사장염(neonatal necrotizing enterocolitis, $\mathrm{NEC}$ ), 뇌실내출혈(intraventricular hemorrhage) 이환 여부를 조사하 여 두 군 간의 차이를 비교하였다. 부당경량아는 출생 시 체중이 10 백분위수 미만인 경우로 정의하였고 ${ }^{15)}$, 신생아 호흡곤란증후군은 산 소 농도 0.4 이상을 필요로 하는 급성 호흡곤란 증상이 있으면서 동시 에 특징적인 흥부 방사선 사진의 변화를 보이고, 인공 폐 표면 활성제 의 사용이 필요한 경우로 정의하였고 ${ }^{16)}$, 기관지폐형성이상은 Jobe 등

${ }^{17)}$ 의 분류법에 따라 생후 28 일 이상 산소 치료가 필요했던 경우로 정 의하였으며, $\mathrm{PDA}$ 는 심장 초음파 검사로 진단 후 약물 치료 또는 수술 적 치료가 필요한 경우로 정의하였다. NEC는 modified bell's staging 
criteria $^{18)}$ 로 정의하였다. 뇌실내출혈은 뇌초음파 검사로 진단하였으 며, 중증도 구분은 Papile의 4단계 분류 기준을 따라 정의하였다 ${ }^{19}$.

산전 스테로이드의 사용 여부와 횟수, 덱사메타손, 도파민, 도부타 민, 푸로세미드, 카페인, 이부프로펜의 사용 여부를 조사하였고, 도파 민과 도부타민의 경우 총투약 시간과 누적 투약 용량을 조사하였으 며, 수혈 여부와 횟수를 조사하여 약물과 수혈이 갑상샘 기능 검사 결 과에 미치는 영향을 조사하였다.

포비돈-아이오딘(povidone-iodine)의 사용이 갑상샘 기능에 미치 는 영향을 확인하기 위해 두 군 간의 수술 여부를 확인하였다. 또한 수술과 같은 스트레스가 갑상샘호르몬에 미치는 영향을 확인하기 위 해 두 군 간의 누적 수술 시간을 비교하였다. 수술은 지연성 TSH 상승 이전에 시행된 것을 조사하였다.

갑상샘호르몬이 장관 운동에 미치는 영향을 확인하기 위해 환자들 의 출생 시점부터 처음으로 태변을 배출하기까지 걸린 시간과 관장 회수, 복부 방사선 검사에서 장이 확장되어 있거나 복부 팽만과 역류 나 구토 등 장관의 움직임 저하나 장폐색 등이 의심되어 금식(nil per $O S, \mathrm{NPO})$ 을 한 경우 그 기간을 확인하여 두 군을 비교하였다. 관장은 변의 배출이 7일 연속 없을 경우에 8일째 되는 날 따뜻한 생리식염수 로 시행하였다. 조사된 NPO 시간은 수술 전후나 시술을 위한 NPO는 제외하였고, 기저 질환과 무관하게 임상적 혹은 영상학적으로 장관 운동성 저하를 보일 때 시행했던 경우로 지연성 TSH 상승이 나타나 기 이전만 포함했다. 장관 운동의 저하로 수유가 느리게 진행되어 하 루 수유량이 $100 \mathrm{cc} / \mathrm{kg} / \mathrm{day}$ 인 장관 영양에 도달하기까지 공급되는 총 정맥영양(total parenteral nutrition, TPN) 기간에서도 두 군 간에서 차 이를 보일 것으로 판단하여 비교하였다.

\section{3. 통계학적 분석}

모든 통계분석은 SPSS software version 24.0 (IBM Corp., Armonk, $\mathrm{NY}, \mathrm{USA})$ 을 이용하였다. 범주형 변수의 집단 간 비교는 카이제곱 검 정(chi-square test) 또는 피셔의 정확 검정(Fisher's exact test)을 이 용하였으며, 빈도(frequency)와 백분율(percentage)로 나타내었다. 연속형 변수의 집단 간 비교는 $t$ 검정(independent sample t-test) 또 는 맨-휘트니 검정(Mann-Whitney's $U$-test)을 이용하였으며, 평균 \pm 표준편차(mean \pm standard deviation)로 표시하였다. 정규성 검정 (normality test)을 위해 샤피로-월크 검정(Shapiro-Wilk's test)을 사 용하였다. 위험인자(risk factor)의 분석을 위해 다변량 로지스틱 회 귀분석(multivariate logistic regression)을 이용하였으며, 이 때 변수 선택(variable selection)을 위해 후진제거법(backward elimination method)을 이용하였다. 또, 공변량(covariates)을 보정한 후 집단 간 차이를 검정하기 위해 공변량분석(analysis of covariance, ANCOVA) 을 수행하였다. $P$ 값이 0.05 미만인 경우 통계적으로 유의하다고 판 단하였다.
결과

\section{1. 환자의 특징}

본 연구에서는 연구 대상 환자를 deTSH군(n=76)과 대조군(n=152) 으로 나누어 두 군 간의 임상 양상 및 특징을 비교하였다. deTSH군은 FT4가 정상이면서 혈청 TSH $5 \mu \mathrm{IU} / \mathrm{mL}$ 이상이었으나 경과 관찰 중 정 상화되어 검사를 종료한 환자를 포함하였고, 대조군은 입원 기간 중 FT4가 정상이면서 혈청 TSH $5 \mu \mathrm{IU} / \mathrm{mL}$ 미만인 환자로 하였다(Figure 1). deTSH군과 대조군 모두 출생 10 일 이내에 시행한 NST에서 TSH 결과는 정상이었다. deTSH군이 신생아집중치료실에 입원 중 지연성 TSH 상승 보인 시기는 총 76명(100\%) 중 53명(69.7\%)이 4주째, 20명 (26.3\%)이 8주째, 3 명(3.9\%)이 12 주째였다. 갑상샘 기능의 호전 시기 는 다음과 같다. 4 주째 지연성 TSH 상승을 보인 53명(100\%)은 48명 (90.6\%)이 6주째, 5명(9.4\%)이 8주째에 TSH가 5 이하로 정상화되었 다. 8 주째 지연성 TSH 상승을 보인 20명(100\%)은 10 주째 15 명(75\%), 12 주째 4명(20\%), 14주째 1명(5\%)이 TSH가 5 이하로 정상화되었 다. 12 주째 지연성 TSH 상승을 보인 3명(100\%)은 14, 16, 18주째 1명 (33.3\%)씩 TSH가 5 이하로 정상화되었다. deTSH군은 72 명 (94.7\%) 이 출생 후 12 주 이내에 TSH가 5 이하로 대부분 정상화되었고 나머지 4 명(5.7\%)이 5 개월 이내에 TSH가 5 이하로 정상화되었다(Figure 1).

총 대상 환자의 남녀 비는 1:1.21이었고, 재태 연령은 29.11士 2.25 주, 출생체중은 $1,157.4 \pm 218.0 \mathrm{~g}$ 이었고, 부당경량아는 24 례 (10.5\%)였다. 제왕절개술로 출생한 신생아는 179 명 $(78.5 \%)$, 다태임 신은 모두 쌍둥이였으며 54례(23.7\%)에서 관찰되었다. 모체의 병 력은 임신성 고혈압(pregnancy-induced hypertension) 7례, 전자간 증(preeclampsia) 10례, 임신성 당뇨(gestational diabetes mellitus) 2 례, 기타 1 례로 총 20 례 $(8.8 \%)$ 가 관찰되었다. 1 분과 5 분 아프가 점 수는 각각 평균 $5.23 \pm 1.81,7.71 \pm 0.98$ 점이었고, deTSH군과 대조 군 두 군 간에 평균 재태 주수 $(P=0.560)$ 와 체중 $(P=0.251)$, 처음으로 태변을 배출하기까지 걸린 시간 $(P=0.465)$, 신생아 호흡곤란증후군 $(P=0.850), \mathrm{PDA}(P=0.850)$, 기관지폐형성이상 $(P=0.919)$, 뇌실내출혈 의 빈도 $(P=0.359), \operatorname{NEC}(P=1.000)$ 는 통계적으로 유의한 차이는 없었 다(Table 1).

\section{2. 치료의 특징}

대상 환아들이 입원 기간 중 자주 노출되었던 약물로는 카페인 $79.8 \%$, 푸로세미드 $61.4 \%$, 이부프로펜 $46.9 \%$, 도파민 $24.1 \%$, 덱사 메타손 $15.8 \%$, 도부타민 3.9\% 순 이었다(Table 2). deTSH군과 대조 군에서 유의한 차이를 보인 약물은 푸로세미드, 도파민, 도부타민 이었다. 푸로세미드는 두 군에서 각각 56명(73.7\%), 84명(55.3\%)에 게 사용되어 통계적으로 유의한 차이를 보였다 $(P=0.007)$. 도파민은 deTSH군에서 35명(46.1\%), 대조군에서 20명(13.2\%)이 사용하였고 $(P=0.000)$, 도부타민은 두 군에서 각각 7 명 $(9.2 \%), 2$ 명 $(1.3 \%)$ 이 사 


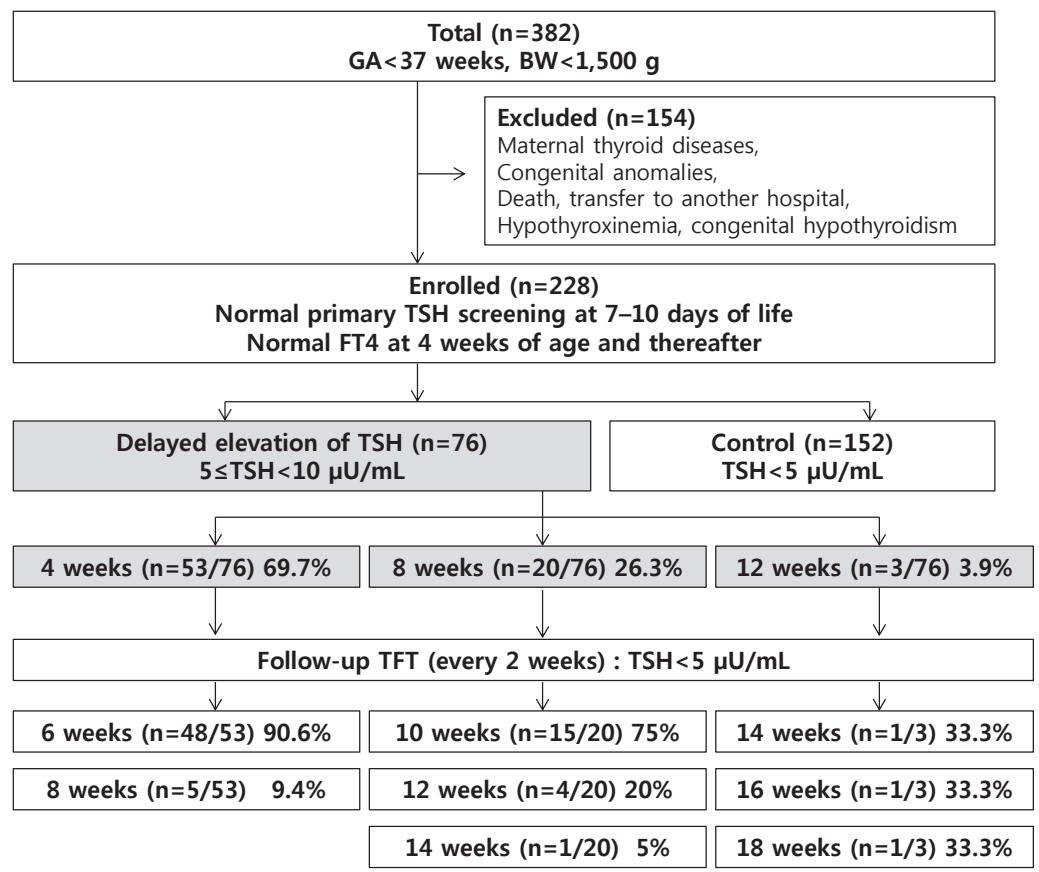

Figure 1. Flowchart showing the study population. This study enrolled 382 premature infants. We excluded 154 infants with history of maternal thyroid disease and/or congenital anomalies, those with hypothyroxinemia, those with congenital hypothyroidism, and those who died. The infants were categorized into two groups on the basis of their serum thyrotropin levels. GA, gestational age; BW, birth weight; TSH, thyroid stimulating hormone; FT4, free thyroxine 4; TFT, thyroid function test.

용하여 $(P=0.007)$ 각각 통계적으로 유의한 결과를 보였다. 도파민의 사용 시간은 deTSH군에서 $144.46 \pm 299.88$ 시간, 대조군에서 $25.46 \pm$ 94.83 시간 $(P=0.000)$, 도파민의 누적 용량은 $\operatorname{deTSH}$ 군에서 69,268士 $159,693 \mu \mathrm{g} / \mathrm{kg}$, 대조군에서 $11,295 \pm 45,032 \mu \mathrm{g} / \mathrm{kg}$ 로 통계적으로 유의 한 결과를 보였다 $(P=0.000)$ (Table 2$)$.

도부타민의 사용 시간은 deTSH군에서 57.66 \pm 245.04 시간, 대조군 에서 $2.91 \pm 25.34$ 시간 $(P=0.004)$, 도부타민의 누적 용량은 $\operatorname{deTSH}$ 군과 대조군에서 각각 $24,095 \pm 104,275 \mu \mathrm{g} / \mathrm{kg}, 1,247 \pm 10,838 \mu \mathrm{g} / \mathrm{kg}$ 으로 통 계적으로 유의하였다 $(P=0.004)$. 수혈은 deTSH군에서 53명(69.7\%), 대조군에서 104 명(68.4\%)이 받았고 $(P=0.840)$, 수혈 횟수는 각 군에

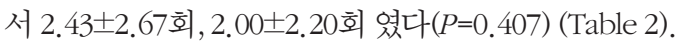

본 연구에서 수술받은 환자들은 총 228명 중 52명(22.8\%)이었 고, deTSH군에서 13명(17.1\%), 대조군에서 39명(25.7\%) 이었다 $(P=$ 0.147 ) (Table 2). 수술은 PDA, 미숙아 망막병증, grade 3 이상의 뇌 실내출혈이 진행한 수두증(hydrocephalus), 서혜부 탈장 및 NEC 등 과 같은 질병에서 총 14 종류의 다양한 수술이 시행되었다. 동맥관 결찰술은 deTSH군 중 수술받은 13 명 중에서 6명(46.2\%), 대조군 은 39명 중에서 23 명 $(58.9 \%)$ 이 받았고 $(P=0.420)$, 아바스타틴 주입 은 deTSH군에서 6명(46.2\%), 대조군에서 4명(10.3\%)이 받았으며 $(P=0.004)$, 레이저광응고술(laser photocoagulation)은 deTSH군에서
4명(30.8\%), 대조군에서 16 명(41\%)이 받았고 $(P=0.510)$, 양측 서혜부 탈장교정수술(both herniorrhaphy)은 deTSH군에서 1명(7.7\%), 대조 군에서 2 명 $(5.1 \%)$ 이 받았다 $(P=0.731)$. 그 외에 좌측 고환고정술(left orchiopexy), 십이지장 공장연결술(duodeno-jejunostomy), 양측 서 혜부탈장교정수술과 고환고정술(orchiopexy), 신생아괴사장염 결 장반절제술(NEC hemicolectomy)과 결장조루술(colostomy), 뇌실외 배액술(external ventricular drainage)이 deTSH군에서만 각각 1명씩 (7.7\%) 시행되었다. 또한 치루 항문성형술(fistula anoplasty), 우측서 혜부탈장교정수술(right herniorrhaphy), 감압술(decompression)과 회장조루술(ileostomy), 위 천공(stomach perforation)의 일차 봉합술 (primary closure), 우측 화농성 고관절 괴사 조직 제거술(right septic hip debridement)과 세척술(irrigation)이 대조군에서만 각각 1명씩 (2.6\%) 시행되었다.

누적 수술 시간이 1시간 이상인 경우는 deTSH군에서 9명(69.2\%), 대조군에서 12 명(30.8\%)으로, deTSH군에서 통계적으로 유의하게 많 았다 $(P=0.014)$ (Table 2).

\section{VLBWI의 지연성 TSH 상승에 영향을 미치는 위험인자}

VLBWI의 지연성 TSH 상승에 영향을 미치는 인자를 다변량 로지 스틱 회귀분석(multivariate logistic regression)을 이용해 분석하였 
Table 1. Baseline Characteristics and Univariate Analysis of Risk Factors for Delayed Elevation of Thyrotropin in Very Low Birth Weight Infants

\begin{tabular}{|c|c|c|c|c|c|c|}
\hline \multirow{2}{*}{ Variable } & \multirow{2}{*}{ Overall (n=228) } & \multicolumn{3}{|c|}{ Group } & \multicolumn{2}{|c|}{ Unifactor analysis } \\
\hline & & $\operatorname{deTSH}(n=76)$ & Control $(n=152)$ & $P$-value & OR (95\% CI) & $P$-value \\
\hline Male sex & $103(45.2)$ & $38(50.0)$ & $65(42.8)$ & $0.301^{*}$ & $1.34(0.77-2.33)$ & 0.301 \\
\hline GA (wk) & $29.11 \pm 2.25$ & $28.99 \pm 2.39$ & $29.17 \pm 2.19$ & $0.562^{\dagger}$ & $\begin{array}{r}1.04(0.92-1.17) \\
(/ \text { wk lower })\end{array}$ & 0.560 \\
\hline $\mathrm{BW}(\mathrm{g})$ & $1,157.4 \pm 218.0$ & $1,133.9 \pm 217.1$ & $1,169.1 \pm 218.2$ & $0.251^{\dagger}$ & $\begin{array}{l}1.08(0.95-1.22) \\
(/ 100 \text { g reduction) }\end{array}$ & 0.251 \\
\hline SGA & $24(10.5)$ & $8(10.5)$ & $16(10.5)$ & $1.000^{*}$ & $1.00(0.41-2.45)$ & 1.000 \\
\hline C-section & $179(78.5)$ & $59(77.6)$ & $120(78.9)$ & $0.820^{*}$ & $0.93(0.48-1.80)$ & 0.820 \\
\hline Multiple birth & $54(23.7)$ & $22(28.9)$ & $32(21.1)$ & $0.186^{*}$ & $1.53(0.81-2.87)$ & 0.188 \\
\hline Maternal history & $20(8.8)$ & $8(10.5)$ & $12(7.9)$ & $0.508^{*}$ & $1.37(0.54-3.51)$ & 0.509 \\
\hline 1 min Apgar score & $5.23 \pm 1.81$ & $5.16 \pm 1.70$ & $5.26 \pm 1.87$ & $0.446^{\ddagger}$ & $\begin{array}{l}1.03(0.89-1.20) \\
\text { (/each point lower) }\end{array}$ & 0.678 \\
\hline 5 min Apgar score & $7.71 \pm 0.98$ & $7.68 \pm 1.01$ & $7.72 \pm 0.96$ & $0.831^{*}$ & $\begin{array}{l}1.04(0.79-1.38) \\
\text { (/each point lower) }\end{array}$ & 0.773 \\
\hline Meconium passage (hr) & $41.75 \pm 66.46$ & $37.18 \pm 64.43$ & $44.03 \pm 67.54$ & $0.978^{*}$ & $1.00(0.99-1.00)$ & 0.465 \\
\hline RDS & $101(44.3)$ & $33(43.4)$ & $68(44.7)$ & $0.850^{*}$ & $0.95(0.54-1.65)$ & 0.850 \\
\hline PDA & $101(44.3)$ & $33(43.4)$ & $68(44.7)$ & $0.850^{*}$ & $0.95(0.54-1.65)$ & 0.850 \\
\hline BPD & $70(30.7)$ & $23(30.3)$ & $47(30.9)$ & $0.919^{*}$ & $0.97(0.53-1.76)$ & 0.919 \\
\hline IVH grade $(\geq 3)$ & $16(7.0)$ & $7(9.2)$ & $9(5.9)$ & $0.359^{*}$ & $1.61(0.58-4.51)$ & 0.363 \\
\hline NEC & $2(0.9)$ & $1(1.3)$ & $1(0.7)$ & $1.000^{\S}$ & $2.01(0.12-32.64)$ & 0.622 \\
\hline
\end{tabular}

Values are expressed as number (\%) or mean \pm standard deviation. Shapiro-Wilk's test was employed for test of normality assumption. A $P<0.05$ represents statistically significant.

${ }^{*} P$-values were derived from chi-square test; ${ }^{\dagger} P$-values were derived from independent t-test; ${ }^{\ddagger} P$-values were derived from Mann-Whitney's $U$-test; ${ }^{\S} P$-values were derived from Fisher's exact test.

Abbreviations : deTSH, delayed elevation of thyrotropin (TSH); OR, odds ratio; CI, confidence interval; GA, gestational age; BW, birth weight; SGA, small for gestational age; C-section, Cesarean section; RDS, respiratory distress syndrome; PDA, patent ductus arteriosus; BPD, bronchopulmonary dysplasia; IVH, intraventricular hemorrhage; NEC, necrotizing enterocolitis.

다. 이때, 단변량 로지스틱 회귀분석에서 유의성이 입증된 변수들을 동시에 고려하여 후진제거법(backward elimination method)을 이용 해 최종적으로 유의한 변수를 선택하였다(Tables 1, 2). 그 결과, 도파 민 사용 여부와 수술 시간인 것으로 나타났다. 도파민을 투여한 군에 서 그렇지 않은 군보다 TSH가 지연 상승될 위험이 8.71배(odds ratio [OR], 8.71; 95\% confidence interval [CI], 1.80- $42.05 ; P=0.007$ )가 높았 다. 그리고 누적 수술 시간이 1 시간 이상일 경우 1 시간 미만에 대비해 서 TSH가 지연 상승될 위험이 6.95배(OR, 6.95; 95\% CI, 1.43-33.75; $P=0.016$ )로 높았다(Table 3).

\section{VLBW|의 지연성 TSH 상승과 위장관 운동과의 관계}

VLBWI의 지연성 TSH 상승에 영향을 미치는 인자로 나타난 도파 민 사용 여부와 수술 시간을 보정한 후 위장관 운동 저하를 의미하 는 NPO 기간(일), 관장 회수, TPN 기간(일)의 차이를 공분산분석을 이용해 분석하였다. 그 결과, $\mathrm{NPO}$ 기간과 TPN 기간이 유의한 차이 가 있는 것으로 나타났으며, 관장 회수는 지연성 TSH 상승과 관련
이 없는 것으로 나타났다( $P$ from ANCOVA=0.930). NPO 기간의 평 균ㅍㅍㅍ준편차는 deTSH군이 $99.87 \pm 134.99$ 시간, 대조군이 $37.25 \pm$ 59.02 시간으로 deTSH군에서 통계적으로 유의하게 길었고 $(P$ from ANCOVA $=0.001), \mathrm{TPN}$ 기간의 평균표죠준편차 역시 deTSH군에서 $33.84 \pm 22.34$ 일, 대조군이 $27.68 \pm 13.08$ 일로 deTSH군에서 통계적으 로 유의하게 길었는데( $P$ from ANCOVA=0.003), 이를 통해 deTSH군 에서 위장관 운동이 의미 있게 감소하여 있음을 알 수 있었다(Table 4).

\section{고찰}

태아의 갑상샘은 재태 연령 12 주에 발생이 완료되어 재태 연령 14 주에 T4와 T3를 생성하고 요오드의 유기화가 이루어진다 ${ }^{20)}$. 임신 제 2 분기부터 태아의 신경 발달이 가속화되고 태아의 갑상샘에서 $\mathrm{T} 4$ 를 분비하지만, 뇌하수체-시상하부-갑상샘 축의 미성숙으로 태아의 갑 
Table 2. Characteristics of Treatment and Univariate Analysis of Risk Factors for Delayed Elevation of Thyrotropin in Very Low Birth Weight Infants

\begin{tabular}{|c|c|c|c|c|c|c|}
\hline \multirow{2}{*}{ Variable } & \multirow{2}{*}{ Overall $(n=228)$} & \multicolumn{3}{|c|}{ Group } & \multicolumn{2}{|c|}{ Unifactor analysis } \\
\hline & & deTSH $(n=76)$ & Control (n=152) & $P$-value & OR $(95 \% \mathrm{CI})$ & $P$-value \\
\hline Prenatal steroid & $173(75.9)$ & $56(73.7)$ & $117(77.0)$ & $0.584^{*}$ & $0.84(0.44-1.58)($ time $)$ & 0.584 \\
\hline No. of prenatal steroid (time) & $1.60 \pm 1.38$ & $1.55 \pm 1.37$ & $1.62 \pm 1.40$ & $0.655^{\dagger}$ & $0.97(0.79-1.18)$ & 0.735 \\
\hline Caffeine & $182(79.8)$ & $61(80.3)$ & $121(79.6)$ & $0.907^{*}$ & $1.04(0.52-2.08)$ & 0.907 \\
\hline Furosemide & $140(61.4)$ & $56(73.7)$ & $84(55.3)$ & $0.007^{*}$ & $2.27(1.24-4.14)$ & 0.008 \\
\hline Ibuprofen & $107(46.9)$ & $33(43.4)$ & $74(48.7)$ & $0.453^{*}$ & $0.81(0.46-1.41)$ & 0.453 \\
\hline Dopamine & $55(24.1)$ & $35(46.1)$ & $20(13.2)$ & $0.000^{*}$ & $5.63(2.94-10.81)$ & 0.000 \\
\hline Duration of infusion (hr) & $65.13 \pm 197.12$ & $144.46 \pm 299.88$ & $25.46 \pm 94.83$ & $0.000^{\dagger}$ & $1.00(1.00-1.01)$ & 0.001 \\
\hline Cumulative dose of infusion $(\mu \mathrm{g} / \mathrm{kg})$ & $30,620 \pm 102,590$ & $69,268 \pm 159,693$ & $11,295 \pm 45,032$ & $0.000^{\dagger}$ & $1.00(1.00-1.00)$ & 0.002 \\
\hline Dexamethasone & $36(15.8)$ & $14(18.4)$ & $22(14.5)$ & $0.441^{*}$ & $1.33(0.64-2.78)$ & 0.442 \\
\hline Dobutamine & $9(3.9)$ & $7(9.2)$ & $2(1.3)$ & $0.007^{*}$ & $7.61(1.54-37.58)$ & 0.013 \\
\hline Duration of infusion (hr) & $21.16 \pm 144.69$ & $57.66 \pm 245.04$ & $2.91 \pm 25.34$ & $0.004^{\dagger}$ & $1.1(1.00-1.01)$ & 0.074 \\
\hline Cumulative dose of infusion $(\mu \mathrm{g} / \mathrm{kg})$ & $8,863 \pm 61,540$ & $24,095 \pm 104,275$ & $1,247 \pm 10,838$ & $0.004^{\dagger}$ & $1.00(1.00-1.00)$ & 0.091 \\
\hline Transfusion & $157(68.9)$ & $53(69.7)$ & $104(68.4)$ & $0.840^{*}$ & $1.06(0.59-1.93)$ & 0.840 \\
\hline No. of RBC transfusions (time) & $2.14 \pm 2.37$ & $2.43 \pm 2.67$ & $2.00 \pm 2.20$ & $0.407^{\dagger}$ & $1.08(0.96-1.21)$ & 0.195 \\
\hline Operations & $52(22.8)$ & $13(17.1)$ & $39(25.7)$ & $0.147^{*}$ & $0.60(0.30-1.20)$ & 0.149 \\
\hline Cumulative operating time ( $\geq 1 \mathrm{hr}$ ) & $21(40.4)$ & $9(69.2)$ & $12(30.8)$ & $0.014^{*}$ & $5.06(1.30-19.72)$ & 0.019 \\
\hline
\end{tabular}

Values are expressed as number (\%) or mean \pm standard deviation. Shapiro-Wilk's test was employed for test of normality assumption.

${ }^{*} P$-values were derived from chi-square test; ${ }^{\dagger} P$-values were derived from Mann-Whitney's $U$-test; ${ }^{\dagger} P$ values were derived from Fisher's exact test.

Abbreviations: deTSH, delayed elevation of thyrotropin (TSH); OR, odds ratio; CI, confidence interval; RBC, red blood cell.

Table 3. Multivariate Logistic Regression Analysis of Risk Factors for Delayed Elevation of Thyrotropin in Very Low Birth Weight Infants

\begin{tabular}{lcc}
\hline \multirow{2}{*}{ Variable } & \multicolumn{2}{c}{ Multifactor analysis } \\
\cline { 2 - 3 } & OR $(95 \% \mathrm{CI})$ & $P$-value \\
\hline Dopamine (yes vs. no) & $8.71(1.80-42.05)$ & 0.007 \\
Cumulative operating time & $6.95(1.43-33.75)$ & 0.016 \\
$(\geq 1$ hr vs. $<1$ hr) & &
\end{tabular}

Abbreviations: OR, odds ratio; CI, confidence interval.

상샘호르몬은 대부분 모체의 갑상샘호르몬이 태반을 통해 태아에게 전달된다고 알려져 있다 ${ }^{21}$. 갑상샘 기능의 조절에 핵심적인 역할을 하는 뇌하수체-시상하부-갑상샘 축은 재태 연령 35-40주까지 성숙이 지속적으로 일어난다 ${ }^{22)}$.

출생 직후 신생아에서 외부 환경에 대한 적응 과정으로 TSH가 급 격히 증가하고 ${ }^{23)}$, 분만 과정 중 혹은 자궁 내에서 심한 스트레스를 받은 신생아와 분만 전후 임산부나 신생아가 요오드에 노출되는 등 의 경우에 일시적으로 TSH가 증가하는 위양성을 보일 수 있다 ${ }^{24)}$. 반 대로 재태 연령 34 주 미만에 출생한 미숙아의 경우에는 뇌하수체-시 상하부-갑상샘 축의 미숙으로 인하여 갑상샘 기능 저하 상태에서도 $\mathrm{TSH}$ 의 상승이 지연될 수 있어 위음성을 보일 수 있다 ${ }^{10)}$. 미숙아에서 그 외의 지연성 TSH 상승의 원인으로는 요오드나 갑상샘 기능에 영
Table 4. Comparison of Gastrointestinal Motility between Infants Belonging to the Delayed Elevation of Thyrotropin and Control Groups

\begin{tabular}{lcccc}
\hline & & \multicolumn{2}{c}{ Group } & \\
\cline { 3 - 4 } Variable & $\begin{array}{c}\text { Overall } \\
(\mathrm{n}=228)\end{array}$ & $\begin{array}{c}\text { deTSH } \\
(\mathrm{n}=76)\end{array}$ & $\begin{array}{c}\text { Control } \\
(\mathrm{n}=152)\end{array}$ & P-value* \\
\hline NPO (hr) & $58.12 \pm 95.98$ & $99.87 \pm 134.99$ & $37.25 \pm 59.02$ & 0.001 \\
No. of enema & $0.39 \pm 0.99$ & $0.33 \pm 0.97$ & $0.41 \pm 1.00$ & 0.930 \\
TPN (d) & $29.73 \pm 16.95$ & $33.84 \pm 22.34$ & $27.68 \pm 13.08$ & 0.003
\end{tabular}

Values are expressed as mean \pm standard deviation.

${ }^{*} P$-values were adjusted for dopamine and operating time in analysis of covariance. These variables were found to be significant to affect delayed elevation of thyrotropin in multivariate logistic regression analysis.

Abbreviations: deTSH, delayed elevation of thyrotropin (TSH); NPO, nil per os (nothing by mouth); TPN, total parenteral nutrition.

향을 미치는 약물들, 선천 심질환 및 미숙아에서 동반되는 각종 질환 들에 의한 동반되는 ESS 등을 들 수 있다 ${ }^{25)}$.

본 연구 대상 VLBWI들은 NST의 TSH 단독 검사에서 모두 정상이 었고, deTSH군의 경우 생후 4주와 12주 사이에 지연성 TSH 상승을 보였다가 경과 관찰 중 정상화되어 검사를 종료한 경우였다. $\mathrm{deTSH}$ 군이 신생아집중치료실에 입원 중 지연성 TSH 상승 보인 시기는 총 76명(100\%) 중 53명(69.7\%)이 4주째, 20명(26.3\%)이 8주째, 3명(3.9 
$\%)$ 이 12 주째였다. 입원 중 또는 외래에서 경과 관찰 중에 TSH 수치가 생후 5 개월 내에 모두 정상 범위로 감소하여 일시적인 경과를 보인 것을 확인하였다. 미숙아는 만삭아에 비해 ESS가 더 빈번하게 발생 하지만 ${ }^{26,27)}$, 대부분 일시적 경과를 보이는 것으로 되어 있으며 ${ }^{28)}$, 일 시적인 ESS에는 일시적인 단독 티록신혈증, 일시적인 신생아 갑상샘 저하증, 일시적인 고갑상샘자극호르몬혈중(hyperthyrotropinemia), ESS 등이 있다 ${ }^{29)}$.

신생아집중치료실에 입원하게 되는 미숙아들은 만삭아에 비해 여 러 질환에 이환되어 환자의 상태가 악화될 경우 도파민과 같은 심장 수축제나 스테로이드, 이뇨제 등과 같은 약물을 사용하게 되는 경우 가 있다. 이들 약물은 TSH 분비를 억제하거나 T4 생성을 억제한다 고 보고되어 있다 ${ }^{12}$. 본 연구에서는 단변량 분석에서 대조군에 비해 deTSH군에서 도파민과 도부타민의 투여가 유의하게 많았고, 다변 량 분석에서 도파민을 투여했을 때 지연성 TSH 상승의 위험이 8.71 배로 유의하게 증가함을 알 수 있었다. Filippi 등 ${ }^{30}$ 은 도파민 또는 도 부타민을 투여받은 35명의 저혈압 VLBWI 연구에서 도파민 투여가 VLBWI의 TSH, 총 티록신, 프로락틴의 혈청 수치를 감소시키지만, 치 료가 중단된 후 신속하게 반등하여 증가하는 것을 확인하였고, 도부 타민 투여는 호르몬의 양상을 변화시키지 않았으며, 치료를 중단한 후에도 반발은 관찰되지 않았다고 보고하였고, 다른 연구에서 TSH 를 억제하는 도파민 용량이 선천 갑상샘저하증의 조기 진단을 억제 할 수 있어서 모든 신생아의 도파민 치료 후갑상샘 기능의 재평가를 권장하였다 ${ }^{31}$. 따라서 신생아집중치료실에 입원한 환자에서 도파민 을 쓰기 전후 갑상샘 기능 검사를 하여 비교하는 것이 필요하고, 지연 성 TSH 상승을 보이는 경우 해석에 주의할 필요가 있다. Zung 등 ${ }^{32)}$ 과 Uchiyama 등 ${ }^{33)}$ 은 다변량 분석에서 푸로세미드가 지연성 TSH 상승의 위험을 각각 3.0 배, 8.3배 증가시킨다고 보고하였는데, 본 연구에서 는 deTSH군에서 단변량 분석 시 푸로세미드에 투여가 유의하게 많았 으나, 다변량 분석에서 위험인자로 확인되지는 않았다. 그 외에 지연 성 TSH 상승의 위험인자가 되는 약물로 Zung 등 ${ }^{32}$ 은 반코마이신, 인 슐린을 보고하였다.

Chung 등 ${ }^{10)}$ 은 재태 연령 32 주 미만의 미숙아의 갑상샘 기능에 영 향을 미치는 요인을 알아보기 위한 연구에서 갑상샘저하증과 일시 적으로 TSH가 상승하였던 미숙아군 각각은 대조군보다 요오드를 함 유한 소독제를 사용하는 외과 수술이 통계적으로 유의하게 많았음 을 확인하여, 요오드 사용이 갑상샘 기능에 영향을 줄 수 있음을 보고 하였다. 그 근거로 미숙아가 갑상샘은 과다한 요오드에 노출될 때 요 오드화물 포획(iodide trapping)을 감소시키는 Wolff-Chaikoff 효과 가 재태 연령 36-40주까지 나타나지 않아서 만삭아보다 갑상샘 억제 효과에 더 민감하고, 요오드 결핍증을 가지고 있어 갑상샘 기능 저하 의 빈도가 높을 수 있다고 하였다. 또한 요오드 함유 소독제가 피부를 통해 흡수될 수 있는데, 미숙아의 피부가 얇아서 쉽게 요오드를 흡수 할 수 있으며, 요오드 함유 소독제에 노출될 수 있는 기회가 많은 것
도 이유라고 설명하였다. 본 연구에서는 Zung 등 ${ }^{32}$ 의 연구에서처럼 deTSH군과 대조군 사이에 외과 수술의 여부가 통계적으로 유의하게 차이가 나지 않았다. 다만, 특정 시술인 Avastin injection (Genentech, San Francisco, CA, USA)이 deTSH군과 대조군 사이에 유의한 빈도 차 이가 있었는데, 본 연구에서 다양한 수술이 시행되었으므로, 더 추가 적인 연구가 필요하리라 생각된다.

ESS는 급 만성 질환이나 영양 결핍 상태 때 몸의 대사작용을 최소 화하고 뇌의 기능을 유지하기 위한 하나의 적응 단계로 알려져 있다 ${ }^{25)}$. ESS는 비갑상샘 질환 증후군(nonthyroidal illness syndrome)이라 고도 하며 갑상샘 기능은 일반적으로 T4, T3 및 TSH가 낮은 특징을 보이는데 ${ }^{34)}, \mathrm{ESS}$ 는 갑상샘 자체의 문제보다는 질병의 중증도를 나타 내는 지표이다. 중증 환자의 혈청 TSH 농도는 감소하지만, 정상 범위 를 초과하는 TSH의 증가가 나타날 수 있고 ${ }^{35)}$, 스트레스 관련 비 갑상 샘 질환으로 인한 회복 중 반등 증가(rebound increase)를 반영할 수 있다 ${ }^{36)}$. 일반적으로 1-2개월 내에 TSH와 T4의 정상화를 나타낸다 ${ }^{35)}$. 본 연구에서는 장시간 수술이 그 자체로 환자에게 스트레스가 되어 $\mathrm{ESS}$ 와 같은 상태로 간접적으로 갑상샘 기능에 영향을 줄 가능성이 클 것으로 생각하고, 누적 수술 시간을 인자로 분석하였다. 단변량 분석 에서 누적 수술 시간이 1 시간 이상 길어질수록 지연성 TSH 상승이 유 의하게 증가함을 확인하였고, 다변량 분석에서 지연성 TSH 상승의 위험이 6.95배로 유의하게 증가한 인자(risk factor)임을 확인하였다. 그 외 지연성 TSH 상승의 위험 요인에 대해 Uchiyama 등 ${ }^{33)}$ 은 부당경 량아, Kaluarachchi 등 ${ }^{37)}$ 은 다태임신, 출생체중, 재태 연령, 5 분 아프 가 점수로 보고하였는데, 본 연구에서는 각 인자에 대한 위험은 관찰 되지 않았다.

본 연구에서는 지연된 TSH 상승이 장관 운동에 영향을 미치는지 알아보고자 하였다. 지연성 TSH 상승에 영향을 미치는 인자로 나타 난 도파민 사용 여부와 수술 시간을 보정한 후 위장관 운동 저하를 의 미하는 NPO기간(일), 관장 회수, TPN기간(일)의 차이를 공분산분 석을 이용해 분석하였다. 갑상샘호르몬이 장관 운동에 작용하는 기 전에 대해서 정확하게 밝혀진 것은 없으나 갑상샘호르몬이 장의 미 세 융모의 구조적, 기능적인 성숙을 도와 장 상피세포의 성장과 분화 에 중요한 역할을 하기 때문에 갑상샘저하증에서 식도 운동의 저하 와 위 배출 지연과 같은 장의 운동 저하가 나타난다고 한다 ${ }^{20,21)}$. 미숙 아에서 흔히 볼 수 있는 수유 장애(feeding intolerance)의 대표적인 증상은 구토나 복부 팽만과 위 내 수유 잔류로 이로 인해 수유 진행 을 더디게 하여 완전 장관영양에 도달하는 시간이 지연되며 TPN 기 간을 연장시킨다 ${ }^{14,38,39)}$. 미숙아 수유 장애의 증상인 위 내 수유 잔류 는 위 배출 지연과 위-십이지장의 운동 저하 또는 십이지장-위 역류 를 반영하며 미성숙한 미숙아의 위장관 기능을 주된 병태 생리로 보 고 있다 ${ }^{14,38,39)}$. Sellappan 등 ${ }^{40)}$ 은 갑상샘저하증을 보인 미숙아에서 가 성 장폐색이 동반된 증례를 보고하였으며, Chung 등 ${ }^{10}$ 도 $\mathrm{ESS}$ 를 보 인 미숙아가 완전 장관영양에 도달하는 기간이 길었다고 보고하였 
다. Choi 등 ${ }^{14}$ 은 갑상샘저하증을 가진 VLBWI와 갑상샘 기능이 정상 인 대조군 연구에서 정맥영양을 위해 사용하는 경피 중심정맥도관의 사용기간이 갑상샘저하증군에서 대조군보다 유의하게 긴 것을 보고 하였다. 본 연구에서도 deTSH군에서 복부 팽만, 구토와 위 내 잔류량 의 증가 등의 위장관 운동 저하로 인해 $\mathrm{NPO}$ 기간이 길어 수유 진행이 늦어지거나 오래 걸렸으며, TPN 기간이 의미 있게 긴 것을 확인하였 다. VLBWI에서 장관영양 진행이 느려 TPN이 필요한 수유 장애를 보 인다면 지연성 TSH 상승을 의심할 필요가 있다. Choi 등 $\left.{ }^{14}\right)$ 은 갑상샘 저하증의 미숙아들이 대조군에 비해 위 내 수유 잔류로 수유 곤란을 겪고 수유량의 감소를 보이는 것을 확인하였고, 갑상샘호르몬 보충 후 증상이 호전되고 장관 수유량이 의미 있게 증가함을 확인하였다. 본 연구에서처럼 갑상샘호르몬 치료를 하지 않았던 일시적인 지연성 $\mathrm{TSH}$ 상승을 보이는 경우 갑상샘호르몬 보충 치료는 논란이 있지만 ${ }^{6,7)}$, 수유 장애를 보이는 경우 갑상샘호르몬 투약을 통해 장관영양의 진행을 원활하게 하여 영양 상태를 개선시켜 이로 인한 미숙아의 뇌 신경 발달을 기대할 수 있을 것이다. 향후 이에 대한 후속 연구가 필 요할 것으로 생각된다.

본 연구의 강점은 VLBWI를 비롯한 미숙아에서 문제가 되는 수유 장애와 지연성 TSH 상승과의 관계를 분석하였다는 것이며, 본 연구 의 제한점은 단일 대학 병원의 환자군을 대상으로 후향적으로 연구 했고, 연구 대상수가 적었고, 기존 보고된 연구들이 지연성 TSH 상승 으로 본 기준치의 다소 낮은 것으로 차이가 있다는 것이다 ${ }^{23,32,33)}$. 현 재까지 보고된 연구들 ${ }^{23,32,33)}$ 에서의 지연성 TSH 상승의 정의와 갑상 샘호르몬 치료 기준에는 차이가 있고 공통된 위험인자가 드물다. 따 라서 향후 지연성 TSH 상승의 기준을 동일화한 전향적인 다기관 대 규모 연구가 필요하리라 사료된다.

결론적으로 저자들은 지연성 TSH 상승을 보였으나 갑상샘호르몬 투약이 필요하지 않았던 VLBWI에서 도파민에 노출된 경우와 수술받 은 누적 시간이 1 시간 이상 길어질수록 지연성 TSH 상승의 위험이 의 미 있게 증가함을 알 수 있었다. VLBWI에서 위장관 운동 저하로 인해 $\mathrm{NPO}$ 기간과 길어 수유 진행이 늦어지는 수유 장애를 보이거나, TPN 기간이 길어질수록 지연성 TSH 상승을 고려해야 함을 알 수 있었다.

\section{이해관계}

본 저자는 이 논문과 관련된 이해관계가 없음.

\section{REFERENCES}

1. Gruters A, Biebermann H, Krude H. Neonatal thyroid disorders. Horm Res 2003;59 Suppl 1:24-9.
2. Smith L. Updated AAP guidelines on newborn screening and therapy for congenital hypothyroidism. Am Fam Physician 2007;76:439-44.

3. Kim JD. Hypothyroidism. Korean J Pediatr 2005;48:779-805.

4. Fisher DA. Thyroid function and dysfunction in premature infants. Pediatr Endocrinol Rev 2007;4:317-28.

5. Vigone MC, Caiulo S, Di Frenna M, Ghirardello S, Corbetta C, Mosca F, et al. Evolution of thyroid function in preterm infants detected by screening for congenital hypothyroidism. J Pediatr 2014;164:1296-302.

6. American Academy of Pediatrics, Rose SR; Section on Endocrinology and Committee on Genetics, American Thyroid Association, Brown RS; Public Health Committee, Lawson Wilkins Pediatric Endocrine Society, Foley T, et al. Update of newborn screening and therapy for congenital hypothyroidism. Pediatrics 2006;117:2290-303.

7. Leger J, Olivieri A, Donaldson M, Torresani T, Krude H, van Vliet G, et al. European Society for Paediatric Endocrinology consensus guidelines on screening, diagnosis, and management of congenital hypothyroidism. Horm Res Paediatr 2014; 81:80-103.

8. Divall SA, Wondisford FE. TRH testing in its infancy. J Clin Endocrinol Metab 2008;93:378-9.

9. Murphy N, Hume R, van Toor H, Matthews TG, Ogston SA, Wu SY, et al. The hypothalamic-pituitary-thyroid axis in preterm infants: changes in the first 24 hours of postnatal life. J Clin Endocrinol Metab 2004;89:2824-31.

10. Chung HR, Shin CH, Yang SW, Choi CW, Kim BI, Kim EK, et al. High incidence of thyroid dysfunction in preterm infants. J Korean Med Sci 2009;24:627-31.

11. Fisher DA. Hypothyroxinemia in premature infants: is thyroxine treatment necessary? Thyroid 1999;9:715-20.

12. Frank JE, Faix JE, Hermos RJ, Mullaney DM, Rojan DA, Mitchell ML, et al. Thyroid function in very low birth weight infants: effects on neonatal hypothyroidism screening. J Pediatr 1996;128:548-54.

13. Smerdely P, Lim A, Boyages SC, Waite K, Wu D, Roberts V, et al. Topical iodine-containing antiseptics and neonatal hypothyroidism in very-low-birthweight infants. Lancet 1989;2:6614.

14. Choi EK, Lee HS, Lee EH, Kim SY, Lee BK, Jung YH, et al. Comparison of enteral feeding in early neonatal period in very low birthweight infants with hypothyroidism. Korean J Perinatol 2015;26:46-52.

15. Battaglia FC, Lubchenco LO. A practical classification of newborn infants by weight and gestational age. J Pediatr 1967;71: 159-63.

16. Charafeddine L, D'Angio CT, Phelps DL. Atypical chronic lung disease patterns in neonates. Pediatrics 1999;103:759-65. 
17. Jobe AH, Bancalari E. Bronchopulmonary dysplasia. Am J Respir Crit Care Med 2001;163:1723-9.

18. Walsh MC, Kliegman RM. Necrotizing enterocolitis: treatment based on staging criteria. Pediatr Clin North Am 1986;33:179201.

19. Volpe JJ. Intracranial hemorrhage: germinal matrix-intraventricular hemorrhage of the premature infant. In: Volpe JJ, editor. Neurology of the newborn. 4th ed. Philadelphia: WB Saunders Co., 2001:428-93.

20. Shepard TH. Onset of function in the human fetal thyroid: biochemical and radioautographic studies from organ culture. J Clin Endocrinol Metab 1967;27:945-58.

21. Contempre B, Jauniaux E, Calvo R, Jurkovic D, Campbell S, de Escobar GM. Detection of thyroid hormones in human embryonic cavities during the first trimester of pregnancy. J Clin Endocrinol Metab 1993;77:1719-22.

22. Morreale de Escobar G, Obregon MJ, Escobar del Rey F. Role of thyroid hormone during early brain development. Eur J Endocrinol 2004;151 Suppl 3:U25-37.

23. Rastogi MV, LaFranchi SH. Congenital hypothyroidism. Orphanet J Rare Dis 2010;5:17.

24. Lee JM, Choi TY, Lee DW, Lee DH. Recheck rate, recall rate and reference range of the neonatal screening test for congenital hypothyroidism. J Clin Pathol Qual Control 2001;23:215-20.

25. Kim EY. Thyroid disorders in premature and sick newborns. Neonatal Med 2015;22:117-23.

26. Fisher DA. Thyroid system immaturities in very low birth weight premature infants. Semin Perinatol 2008;32:387-97.

27. Kim SY, Han MY, Lee KH. Thyroid function in preterm infants with respiratory distress syndrome and bronchopulmonary dysplasia. J Korean Soc Neonatal 2001;8:94-102.

28. Hong KB, Park JY, Chang YP, Yu J. Thyroid dysfunction in premature infants. Korean J Pediatr 2009;52:991-8.

29. Guy VV, Johnny D. Disorders of the thyroid in the newborns and infant. In: Sperling MA, editor. Pediatric endocrinology. 4th ed. Philadelphia: Elsevier Saunders, 2014:186-208.
30. Filippi L, Pezzati M, Poggi C, Rossi S, Cecchi A, Santoro C. Dopaine versus dobutamine in very low birthweight infants: endocrine effects. Arch Dis Child Fetal Neonatal Ed 2007;92: F367-71.

31. Filippi L, Pezzati M, Cecchi A, Poggi C. Dopamine infusion: a possible cause of undiagnosed congenital hypothyroidism in preterm infants. Pediatr Crit Care Med 2006;7:249-51.

32. Zung A, Bier Palmon R, Golan A, Troitzky M, Eventov-Friedman S, Marom R, et al. Risk factors for the development of delayed TSH elevation in neonatal intensive care unit newborns. J Clin Endocrinol Metab 2017;102:3050-5.

33. Uchiyama A, Watanabe H, Nakanishi H, Totsu S. Small for gestational age is a risk factor for the development of delayed thyrotropin elevation in infants weighing less than 2000 g. Clin Endocrinol (Oxf) 2018;89:431-6.

34. Marks SD. Nonthyroidal illness syndrome in children. Endocrine 2009;36:355-67.

35. Hamblin PS, Dyer SA, Mohr VS, Le Grand BA, Lim CF, Tuxen $\mathrm{DV}$, et al. Relationship between thyrotropin and thyroxine changes during recovery from severe hypothyroxinemia of critical illness. J Clin Endocrinol Metab 1986;62:717-22.

36. Bacci V, Schussler GC, Kaplan TB. The relationship between serum triiodothyronine and thyrotropin during systemic illness. J Clin Endocrinol Metab 1982;54:1229-35.

37. Kaluarachchi DC, Colaizy TT, Pesce LM, Tansey M, Klein JM. Congenital hypothyroidism with delayed thyroid-stimulating hormone elevation in premature infants born at less than 30 weeks gestation. J Perinatol 2017;37:277-82.

38. Fanaro S. Feeding intolerance in the preterm infant. Early Hum Dev 2013;89 Suppl 2:S13-20.

39. Jadcherla SR, Kliegman RM. Studies of feeding intolerance in very low birth weight infants: definition and significance. Pediatrics 2002;109:516-7.

40. Sellappan B, Chakraborty M, Cherian S. Congenital hypothyroidism presenting as pseudo-obstruction in preterm infants. BMJ Case Rep 2014;2014:bcr2013201082. 